\title{
First Degree Perineal Laceration
}

National Cancer Institute

\section{Source}

National Cancer Institute. First Degree Perineal Laceration. NCI Thesaurus. Code C114104.

Injury to perineal skin only. (reVITALize) 